\title{
Weed Management Strategies in Pigeonpea under Alfisol and Vertisol
}

\author{
Shruti Suman ${ }^{1,2}$, Myer G Mula ${ }^{1}$, Gurusharan Panwar $^{2}$, Sanjay Kumar ${ }^{2}$ and \\ Mainak Ghosh ${ }^{2 *}$ \\ ${ }^{1}$ International Crops Research Institute for the Semi-Arid Tropics (ICRISAT), Patancheru, Hyderabad, India \\ ${ }^{2}$ Department of Agronomy, Bihar Agricultural University, Sabour 813 210, Bhagalpur, India \\ *Corresponding Author E-mail: mainakghosh999@gmail.com \\ Received: 6.08.2017 | Revised: 15.09.2017 | Accepted: 18.09.2017
}

\begin{abstract}
A field experiment was conducted during the cropping season of 2013-14 at Patancheru, Telangana to find out the economic weed management option and to study the impact of weed management practices on yield of pigeonpea under two different soil types (Alfisol and Vertisol). Pigeonpea (Cajanus cajan L.) is a versatile legume crop in many parts of the world. In India, the productivity of pigeonpea has remained stagnant due to the several constraints in pulse production. Among the several constraints, associated with pigeonpea weed infestation has a lion's share. Herbicides were applied in each plot of Alfisol and Vertisol according to the dose and the twelve same set of treatment were replicated thrice in randomized block design. Result revealed that Alfisol perform better in term of weed control efficiency while the observed yield and net return were more in Vertisol compared to Alfisol. In Alfisol, significantly lower weed index of $12.48 \%$ was recorded in imazethapyr 10\% SL @60 g a.i./ha at 15 DAS $\left(T_{3}\right)$ while imazethapyr 10\% SL @ $40 \mathrm{~g}$ a.i./ha at $15 \mathrm{DAS}\left(\mathrm{T}_{2}\right)$ recorded the index of 12.23\% in Vertisol which gave higher seed yield of 1907 and $2345 \mathrm{~kg} / \mathrm{ha}$ in Alfisol and Vertisol, respectively. The use of herbicide to suppress weeds during the early vegetative stage of pigeonpea was effective in both soil types.
\end{abstract}

Key words: Weed management, yield, weed control efficiency, pigeonpea

\section{INTRODUCTION}

Pigeonpea [Cajanus cajan (L.) Millspaugh] is a versatile food legume crop of the semi-arid tropics. It is predominantly cultivated in the developing countries of tropical and subtropical environments between $30^{\circ} \mathrm{N}$ and $30^{\circ} \mathrm{S}$ latitudes. In India, the area under pigeonpea has recorded a significant rise, but the productivity has remained stagnant at around $774 \mathrm{~kg} / \mathrm{ha}$ over the last five decades ${ }^{13}$. The yield gap between national productivity and global productivity can be achieved by managing various abiotic and biotic stresses which limits the productivity.

Cite this article: Suman, S., Mula, M.G., Panwar, G., Kumar, S. and Ghosh , M., Weed Management Strategies in Pigeonpea under Alfisol and Vertisol, Int. J. Pure App. Biosci. 5(6): 138-143 (2017). doi: http://dx.doi.org/10.18782/2320-7051.5353 
Among the several constraints, associated with pigeonpea productivity, the biotic factors, weeds are major impediments. Considered a wet season crop, the intermittent rains facilitate the growth of weeds including the narrow and broad-leaved weed. Weeds are the leading constraints in pigeonpea production through their ability to compete for resources and their adverse impact on quality. Further, as it is a long duration crop and weeds emerge in different flushes at later stages. It has been observed that, on an average, weed can reduce pigeonpea yield by $80 \%^{16}$. Moreover, the wider row spacing and initial slow growth of pigeonpea facilitate growth of weed which may lead to reduction in yield of pigeonpea by $40-64 \%^{1}$. The long critical period (5-6 weeks) of crop-weed competition compels the farmers to maintain the field weed free and in this regard twice hand weeding during 15 and 45 days after sowing (DAS) has resulted in better crop growth and higher grain yield in pigeonpea $^{18}$. However, the management practice of manual weeding is not feasible due to labour shortage and engagement of labour in paddy transplanting. Chemical weed control measures appear more convenient, less time consuming, less expensive and provide a weed free condition for the early establishment of crop plants. Herbicide like imazethapyr and quizalofop-ethyl can be used effectively to control weeds in soybean and groundnut. But information on their usage, suitability and concentration for effective control of weeds in pigeonpea is limited. Pre-emergence herbicide pendimethalin has been found effective in pulses and can improve the yield ${ }^{11}$. Many other pre-emergence herbicides viz., metalachlor ${ }^{9}$, alachlor ${ }^{17}$ and post-emergence herbicide such as imazethapyr have also been tested effectively in pigeonpea. The use of pendimethalin and other pre-emergence herbicide is restricted due to unfavourable weather conditions. In such situations, postemergence herbicides of wide window like imazethapyr may be applied as early post and late post-emergence to kill the complex weed flora. Keeping these above facts in view, the present research was undertaken to find out the effective weed management practices in terms of yield as well as economics under two different soil types.

\section{MATERIAL AND METHODS}

Experiments were conducted at ICRISAT (International Crops Research Institute for Semi Arid Tropics), Patancheru, Telangana, India during wet season of 2013-14. The experiments were laid out in randomized block design, replicated thrice. In the first experiment, the soil was Alfisol with twelve treatments and for the second experiment it was Vertisol with the same set of treatments and replications. The variety, Pusa-9 was common for both the experiments. The treatments were as follows: Imazethapyr $10 \%$ SL @ $20 \mathrm{~g}$ a.i. /ha at 15 DAS $\left(\mathrm{T}_{1}\right)$, Imazethapyr $10 \% \mathrm{SL} @ 40 \mathrm{~g}$ a.i. /ha at 15 DAS $\left(\mathrm{T}_{2}\right)$, Imazethapyr $10 \% \mathrm{SL} @ 60 \mathrm{~g}$ a.i. /ha at 15 DAS $\left(\mathrm{T}_{3}\right)$, Imazethapyr $10 \%$ SL @ $20 \mathrm{~g}$ a.i. /ha at $30 \mathrm{DAS}\left(\mathrm{T}_{4}\right)$, Imazethapyr $10 \%$ SL @ 40 g a.i. /ha at 30 DAS $\left(\mathrm{T}_{5}\right)$, Imazethapyr $10 \% \mathrm{SL} @ 60 \mathrm{~g}$ a.i. /ha at 30 DAS $\left(\mathrm{T}_{6}\right)$, application of Pendimethalin $30 \%$ EC @ $750 \mathrm{~g}$ a.i. /ha as pre emergence (PE) $\left(\mathrm{T}_{7}\right)$, application of Pendimethalin 30\% EC @ $750 \mathrm{~g}$ a.i. /ha as PE + Quizalofop-ethyl $5 \%$ EC @ $50 \mathrm{~g}$ a.i. /ha as post emergence (POE) at 15 DAS $\left(\mathrm{T}_{8}\right)$, intercropping of Pigeonpea + blackgram $\left(\mathrm{T}_{9}\right)$, application of Metribuzin $70 \%$ WP @ $250 \mathrm{~g}$ a.i /ha as PE $\left(\mathrm{T}_{10}\right)$, un-weeded control $\left(\mathrm{T}_{11}\right)$ and weed free $\left(\mathrm{T}_{12}\right)$. Pigeonpea variety, Pusa-9 was sown at a row-to-row distance of $75 \mathrm{~cm}$ and plant-to-plant distance of $30 \mathrm{~cm}$ in six rows. The $\mathrm{pH}$ of the experimental field before sowing was 7.37 in Alfisol and 7.68 in Vertisol. The crop was fertilized with DAP @ 100 kg/ha. Irrigation was given two times (first at flowering and second at pod filling stage). Four hand weeding; each at 15 days interval was carried out in weed free $\left(\mathrm{T}_{12}\right)$. Calculated quantities of herbicides with a spray fluid of 500 liters/ha were applied in the herbicidal plots through knapsack sprayer using flat fan nozzle as per the treatment.

The grain yield and yield attributes were recorded at harvest. Total cost involved 
was calculated by adding the treatment cost of weed control with common cost of production of pigeonpea. Weed population and weed dry matter were recorded at 30,60 and 90 DAS by using a quadrate of size $0.5 \mathrm{~m}^{2}$. The above ground weed biomass was measured and the original data were subjected to square root transformation by using the formula $\sqrt{ } \mathrm{X}+0.5^{2}$ and analysed statistically. Weed control efficiency (WCE) was calculated on dry weight basis by adopting the formula given by Mani $e t a l^{8}$.

$$
\text { WCE }=\frac{\text { Weed biomasss in weedy check plot }- \text { Weed biomass in treated plot }}{\text { Weed biomasss in weedy check plot }} \times 100
$$

Weed index is reduction in yield due to weed infestation. It is calculated by using the formula given by Gill and Kumar (1969).

$$
\mathrm{WI}=\frac{\text { Yield of weed free plot }- \text { Yield of treated plot }}{\text { Yield of weed free plot }} \times 100
$$

All the parameters were statistically analyzed by using analysis of variance techniques (ANOVA) as described by Cochran and $\mathrm{Cox}^{3}$ for testing the significant difference among various treatments at $5 \%$ level of significance. Standard error of mean (SEm \pm ) and least significant difference (LSD) at 5\% level of significance were worked out for each character to compare the difference between the treatment means.

\section{RESULTS AND DISCUSSION Weed flora}

The study showed that common weeds grown in Alfisol and Vertisol were grassy (Echinocloa colona, Paspalum distichum, Digitaria sanguinalis, Eleusine indica, Dactyloctenium aegyptium); Broad leaf (Digera arvensis, Parthenium hysterophorus, Commelina benghalensis, Bidens biternata), and sedge (Cyperus rotundus). However, weeds like Chloris barbata and Celosia argentea were only observed in Alfisol. Weed dry matter calculated at 60 DAS was more in Vertisol may be due to more available soil moisture in Vertisol. Weedy check (Unweeded control plot) recorded the highest weed dry matter in Alfisol as well as Vertisol (Table 1 and 2). All the treatments significantly reduced the weed dry matter compared to weedy check $\left(\mathrm{T}_{11}\right)$ due to the reduction in weed growth in both soil. Singh and Sekhon ${ }^{14}$ also reported highest weed dry matter in un-weeded control plot. The treatment $\mathrm{T}_{3}$ recorded significantly lower weed dry matter $\left(3.72 \mathrm{~g} / \mathrm{m}^{2}\right)$ and was statistically at par with $\mathrm{T}_{6}\left(4.41 \mathrm{~g} / \mathrm{m}^{2}\right)$ and $\mathrm{T}_{2}\left(4.45 \mathrm{~g} / \mathrm{m}^{2}\right)$ resulting higher weed control efficiencies in Alfisol (Table 1) and this is due to effective control of weed by imazethapyr applied at 15 DAS and 30 DAS. The mixed formulation of pendimethalin 30\% EC @ 750g.a.i./ha as pre emergence followed by quizalofop-ethyl $5 \%$ EC@ 50g. a.i./ha as poat emergence $\left(\mathrm{T}_{8}\right)$ also reduced the weed dry matter and recorded the weed control efficiency of $75.23 \%$. As pendimethalin is effective only up to one month hence for further control of weed the treatment of mixed formulation $\left(\mathrm{T}_{8}\right)$ was taken which controlled the weed at later stage also. Shalini and Singh ${ }^{12}$ also reported similar findings with the application of pendimethalin $1000 \mathrm{~g} / \mathrm{ha}$ (PE) + quizalofopethyl $50 \mathrm{~g} / \mathrm{ha}$ (POE) in dwarf field pea. $\mathrm{T}_{3}$ recorded significantly lower weed index $(12.48 \%)$. In the second experiment under vertisol, significantly lower weed dry matter $\left(6.03 \mathrm{~g} / \mathrm{m}^{2}\right)$ was recorded in $\mathrm{T}_{2}$ which was statistically at par with $\mathrm{T}_{3}\left(6.23 \mathrm{~g} / \mathrm{m}^{2}\right)$ and $\mathrm{T}_{6}$ $\left(6.25 \mathrm{~g} / \mathrm{m}^{2}\right)$ resulting in higher weed control efficiencies of $70.23 \%, 69.76 \%$ and $65.26 \%$. The results were similar to the findings of Padmaja et al. ${ }^{10}$ and Goud et al. ${ }^{6}$ in pigeonpea and chickpea, respectively. Weedy check (Unweeded control) recorded highest weed index $(43.03 \%)$ and lowest in weed free $\left(\mathrm{T}_{12}\right)$ as shown in Table 2. $\mathrm{T}_{2}$ recorded significantly lower weed index (12.23\%) followed by 
application of imazethapyr @ 60g a.i./ha as post emergence $\left(\mathrm{T}_{3}\right)$ which registered the weed index of $20.66 \%$.

\section{Crop yield}

There was a significant variation in seed yield of pigeonpea on both soil types. The weed free treatment i.e. $\mathrm{T}_{12}$ recorded highest grain yield (2180 kg/ha) and biomass yield (9247 kg/ha). These findings were similar to the results of Dhonde et $a l^{4}{ }^{4}$. Among the herbicidal treatments, imazethapyr @60 g a.i./ha at 15 DAS i.e. $\mathrm{T}_{3}$ registered significantly higher grain yield (1907 kg/ha), which was statistically at par with $\mathrm{T}_{6}(1843 \mathrm{~kg} / \mathrm{ha})$ (Table $1)$. The higher yield was due to higher weed control efficiency of $87.37 \%$ and $83.00 \%$ in $\mathrm{T}_{3}$ and $\mathrm{T}_{6}$, respectively than the others. In second experiment, highest grain yield was also recorded in $\mathrm{T}_{12}$ treatment $(2672 \mathrm{~kg} / \mathrm{ha})$ which was significantly higher over the others (Table 2). Here in Vertisol, $T_{2}$ recorded the significantly higher grain yield of $2345 \mathrm{~kg} / \mathrm{ha}$ which was found statistically at par with treatment $\mathrm{T}_{5}(2318 \mathrm{~kg} / \mathrm{ha})$ and $\mathrm{T}_{3}(2248 \mathrm{~kg} / \mathrm{ha})$. Over-all, there was an increase in the yield of pigeonpea from utilizing herbicides to control weeds for both soil type which conforms to the findings of Kelly et al. ${ }^{7}$ and Reddy et al. ${ }^{11}$ than weedy check plot $\left(\mathrm{T}_{11}\right)$.The weed free treatment i.e. $\mathrm{T}_{12}$ registered maximum biomass yield (9942 kg/ha) due to zero crop weed competition throughout the crop growth period.

\section{Economics}

In this study it was observed that pigeonpea grown in Vertisol gives more income than in Alfisol, as in the second experiment, the yield was found higher in almost all the cases as compared to that of first experiment. Data presented in Table 1 revealed that the highest net return was recorded in $\mathrm{T}_{3}$ ( $\mathrm{Rs}$ 47,067/ha) with $\mathrm{B}: \mathrm{C}$ ratio of 1.81 followed by $\mathrm{T}_{6}$ and $\mathrm{T}_{2}$. The net return was lowest in $\mathrm{T}_{11}$ (Rs $22,638 /$ ha) due to lowest yield resulting in lowest gross return. Similar kinds of results were also reported by Suman et al. ${ }^{15}$. In Vertisol, imazethapyr @ $40 \mathrm{~g}$ a.i./ha at 15 DAS i.e. $T_{2}$ registered the highest net return (Rs 63,945/ha) followed by $\mathrm{T}_{5}$ (Rs 63,161/ha) with $\mathrm{B}: \mathrm{C}$ ratio of $2.48,2.45$, respectively. Based on the results it was observed that the yield differed significantly among the treatments in respective soil types. Application of imazethapyr @ $40 \mathrm{~g}$ a.i./ha at $15 \mathrm{DAS}\left(\mathrm{T}_{2}\right)$, imazethapyr @60 g a.i./ha at 15 DAS $\left(\mathrm{T}_{3}\right) \&$ imazethapyr @60 g a.i./ha at 30 DAS ( $\left.\mathrm{T}_{6}\right)$ performed well in terms of yield as well as economics in both the experiments.

Table 1: Effect of weed management on yield and economics of pigeonpea under Alfisol

\begin{tabular}{|c|c|c|c|c|c|c|c|}
\hline Treatment Details & $\begin{array}{l}\text { Grain } \\
\text { yield } \\
(\mathrm{kg} / \mathrm{ha})\end{array}$ & $\begin{array}{l}\text { Biomass } \\
\text { yield } \\
(\mathrm{kg} / \mathrm{ha})\end{array}$ & $\begin{array}{l}\text { Weed dry } \\
\text { matter } \\
\text { at } 60 \text { DAS } \\
\left(\mathrm{g} / \mathrm{m}^{2}\right) \\
\end{array}$ & $\begin{array}{l}\text { WCE } \\
(\%) \text { at } 60 \\
\text { DAS }\end{array}$ & WI (\%) & $\begin{array}{l}\text { Net Return } \\
\text { (Rs./ha) }\end{array}$ & $\begin{array}{l}\mathrm{B}: \mathrm{C} \\
\text { ratio }\end{array}$ \\
\hline $\begin{array}{l}\mathrm{T}_{1} \text { - Imazethapyr } 10 \% \text { SL @ 20g a.i./ha } \\
\text { at } 15 \text { DAS }\end{array}$ & 1665 & 7135 & $6.49(42.67)$ & 58.15 & 23.64 & 38,328 & 1.51 \\
\hline $\begin{array}{l}\mathrm{T}_{2} \text { - Imazethapyr } 10 \% \text { SL @ 40g a.i./ha } \\
\text { at } 15 \text { DAS }\end{array}$ & 1730 & 7351 & $4.45(19.33)$ & 82.01 & 20.66 & 40,449 & 1.57 \\
\hline $\begin{array}{l}\mathrm{T}_{3} \text { - Imazethapyr } 10 \% \text { SL @ 60g a.i./ha } \\
\text { at 15 DAS }\end{array}$ & 1907 & 8274 & $3.72(13.33)$ & 87.37 & 12.48 & 47,067 & 1.81 \\
\hline $\begin{array}{l}\mathrm{T}_{4} \text { - Imazethapyr } 10 \% \text { SL @ 20g a.i./ha } \\
\text { at } 30 \text { DAS }\end{array}$ & 1622 & 6732 & $6.82(46.67)$ & 58.81 & 25.59 & 36,457 & 1.43 \\
\hline $\begin{array}{l}\mathrm{T}_{5} \text { - Imazethapyr } 10 \% \text { SL @ 40g a.i./ha } \\
\text { at } 30 \text { DAS }\end{array}$ & 1750 & 7639 & $5.79(33.67)$ & 70.77 & 19.77 & 41,392 & 1.61 \\
\hline $\begin{array}{l}\mathrm{T}_{6} \text { - Imazethapyr10\% SL @ 60g a.i./ha at } \\
30 \text { DAS }\end{array}$ & 1843 & 8014 & $4.41(19.00)$ & 83.00 & 15.45 & 44,607 & 1.71 \\
\hline $\begin{array}{l}\mathrm{T}_{7} \text { - Pendimethalin } 30 \% \text { EC @ 750g. } \\
\text { a.i./ha as PE }\end{array}$ & 1642 & 6852 & $7.12(51.00)$ & 51.89 & 24.66 & 36,448 & 1.39 \\
\hline $\begin{array}{l}\mathrm{T}_{8} \text { - Pendimethalin } 30 \% \text { EC @ } 750 \mathrm{~g} . \\
\text { a.i./ha as PE+ Quizalofop-ethyl 5\% EC } \\
\text { @ 50g. a.i./ha as POE }\end{array}$ & 1658 & 7044 & $5.35(28.33)$ & 75.23 & 23.89 & 35,504 & 1.27 \\
\hline $\mathrm{T}_{9}$ - Pigeonpea+ blackgram intercropping & 1357 & 5789 & $6.69(44.33)$ & 59.16 & 37.79 & 29,270 & 1.13 \\
\hline $\begin{array}{l}\mathrm{T}_{10}-\text { Metribuzin } 70 \% \text { WP @ } 250 \mathrm{~g} . \\
\text { a.i./ha as PE }\end{array}$ & 1573 & 6650 & $6.80(46.00)$ & 58.45 & 27.82 & 34,381 & 1.34 \\
\hline $\mathrm{T}_{11}-$ Weedy check & 1241 & 5229 & $10.42(109.33)$ & 0.00 & 43.03 & 22,638 & 0.91 \\
\hline $\mathrm{T}_{12}-$ Weed free & 2180 & 9247 & $0.71(0.00)$ & 100.00 & 0.00 & 43,577 & 1.09 \\
\hline $\operatorname{SEm}( \pm)$ & 57.1 & 221 & 0.45 & 2.42 & 2.61 & & \\
\hline $\mathrm{CD}$ at $5 \%$ & 167.4 & 647 & 1.33 & 7.12 & 7.66 & & \\
\hline
\end{tabular}


Figure in parenthesis indicate the original value; DAS = Days after sowing

Table 2: Effect of weed management on yield and economics of pigeonpea under Vertisol

\begin{tabular}{|c|c|c|c|c|c|c|c|}
\hline Treatment Details & $\begin{array}{l}\text { Grain } \\
\text { yield } \\
\text { (kg/ha) }\end{array}$ & $\begin{array}{l}\text { Biomass } \\
\text { yield } \\
(\mathrm{kg} / \mathrm{ha})\end{array}$ & $\begin{array}{l}\text { Weed dry } \\
\text { matter } \\
\text { at } 60 \text { DAS } \\
\left(\mathrm{g} / \mathrm{m}^{2}\right)\end{array}$ & $\begin{array}{l}\text { WCE } \\
(\%) \text { at } 60 \\
\text { DAS }\end{array}$ & $\begin{array}{l}\text { WI } \\
(\%)\end{array}$ & $\begin{array}{l}\text { Net Return } \\
\text { (Rs./ha) }\end{array}$ & $\begin{array}{l}\mathrm{B}: \mathrm{C} \\
\text { ratio }\end{array}$ \\
\hline $\begin{array}{l}\mathrm{T}_{1} \text { - Imazethapyr } 10 \% \text { SL @ 20g a.i./ha } \\
\text { at } 15 \text { DAS }\end{array}$ & 2044 & 8720 & $8.23(67.67)$ & 57.91 & 23.42 & 52,795 & 2.08 \\
\hline $\begin{array}{l}\mathrm{T}_{2} \text { - Imazethapyr } 10 \% \mathrm{SL} @ 40 \mathrm{~g} \text { a.i./ha } \\
\text { at } 15 \mathrm{DAS}\end{array}$ & 2345 & 9942 & $6.03(36.10)$ & 70.23 & 12.23 & 63,945 & 2.48 \\
\hline $\begin{array}{l}\mathrm{T}_{3} \text { - Imazethapyr } 10 \% \text { SL @ 60g a.i./ha } \\
\text { at } 15 \text { DAS }\end{array}$ & 2248 & 9687 & $6.23(38.50)$ & 69.76 & 15.84 & 60,072 & 2.31 \\
\hline $\begin{array}{l}\mathrm{T}_{4} \text { - Imazethapyr } 10 \% \text { SL @ 20g a.i./ha } \\
\text { at } 30 \text { DAS }\end{array}$ & 1894 & 7817 & $8.70(75.23)$ & 50.75 & 29.05 & 46,792 & 1.84 \\
\hline $\begin{array}{l}\mathrm{T}_{5} \text { - Imazethapyr } 10 \% \text { SL @ } 40 \mathrm{~g} \text { a.i./ha at } \\
30 \text { DAS }\end{array}$ & 2318 & 10085 & $6.84(46.43)$ & 62.18 & 13.21 & 63,161 & 2.45 \\
\hline $\begin{array}{l}\mathrm{T}_{6} \text { - Imazethapyr10 \% SL @ 60g a.i./ha at } \\
30 \text { DAS }\end{array}$ & 2324 & 10129 & $6.25(38.60)$ & 65.26 & 13.04 & 63,071 & 2.42 \\
\hline $\begin{array}{l}\mathrm{T}_{7} \text { - Pendimethalin } 30 \% \mathrm{EC} @ 750 \mathrm{~g} . \\
\text { a.i./ha as PE }\end{array}$ & 1778 & 7411 & $8.87(78.30)$ & 38.93 & 33.42 & 41,628 & 1.59 \\
\hline $\begin{array}{l}\mathrm{T}_{8} \text { - Pendimethalin } 30 \% \text { EC @ 750g. } \\
\text { a.i./ha as PE+ Quizalofop-ethyl 5\% EC @ } \\
\text { 50g. a.i./ha as POE }\end{array}$ & 1809 & 7677 & $8.06(64.53)$ & 43.07 & 32.20 & 41,259 & 1.48 \\
\hline $\mathrm{T}_{9}$ - Pigeonpea+ blackgram intercropping & 1956 & 8343 & $9.18(84.00)$ & 32.74 & 26.83 & 52,537 & 2.04 \\
\hline $\begin{array}{l}\mathrm{T}_{10}-\text { Metribuzin } 70 \% \text { WP @ } 250 \mathrm{~g} . \\
\text { a.i./ha as PE }\end{array}$ & 1710 & 7235 & $9.53(90.53)$ & 44.76 & 36.06 & 39,629 & 1.54 \\
\hline $\mathrm{T}_{11}-$ Weedy check & 1640 & 6926 & $12.40(153.50)$ & 0.00 & 38.52 & 37,886 & 1.53 \\
\hline $\mathrm{T}_{12}-$ Weed free & 2672 & 11304 & $0.71(0.00)$ & 100.00 & 0.00 & 62,353 & 1.57 \\
\hline $\operatorname{SEm}( \pm)$ & 59.7 & 309 & 0.28 & 3.64 & 2.19 & & \\
\hline $\mathrm{CD}$ at $5 \%$ & 175.2 & 906 & 0.82 & 10.70 & 6.42 & & \\
\hline
\end{tabular}

Figure in parenthesis indicate the original value; DAS = Days after sowing

\section{REFERENCES}

1. Ahlawat, I. P. S., Gangaiah, B. and Singh, I. P. Pigeonpea (Cajanus cajan) research in India-an overview. Indian Journal of Agricultural Sciences 75(6): 309-320 (2005).

2. Chandel, S. R. S. Analysis of Variance. A Handbook of Agricultural Statistics. 7th Edition, Achal Prakashan Mandhir. 358359 (1984).

3. Cochran, W. G. and Cox, G. M. Experimental Designs, Second Edition, Asia publishing House, Bombay, India: 576 (1985).

4. Dhonde, M. B., Kate, S. R., Pandure, B. S. and Tambe, A. D. Integrated weed management in pigeonpea. Indian Journal of weed science 41(1\&2): 102-105 (2009).

5. Gill, H. S. and Kumar, V. "Weed Index"a new method for reporting weed control trials. Indian Journal of Agronomy 14(1): 96-98 (1969).

6. Goud, V. V., Murade, N. B., Khakre, M. S. and Patil, A. N. Efficacy of imazethapyr and quizalofop-ethyl herbicides on growth and yield of chickpea. The Bioscan 8(3): 1015-1018 (2013).
7. Kelly, A. N., Renner, K. A. and Donald, P. Weed control in soybean (Glycine max) with imazomox and imazethapyr. Weed Science 46(5): $594-594$ (1998).

8. Mani, V. S., Chakraborty, T. K. and Gautam, K. C. Double edged killers in peas. Indian farming 26: 19-21 (1976).

9. Nagaraju, A. P. and Kumar, H. K. M. Efficacy of herbicides on weed control in pigeonpea [Cajanus cajan (L.) Millsp.]. Mysore Journal of Agricultural Science 43(2): 201-204 (2009).

10. Padmaja, B., Reddy, M. M., Reddy, D. and Vishnu, V. Weed control efficiency of pre-and post- emergence herbicides in pigeon pea (Cajanus cajan L.). Journal of Food Legumes 26 (1 and 2): 44-457 (2013).

11. Reddy, M. M., Vilatha, A. M. and Rao, L. J. Integrated weed management in pigeonpea (Cajanus cajan)-soybean (Glycine max) intercropping system on Vertisol under rainfed conditions. Indian Journal of Agricultural Science 77(3): 177-178 (2007).

12. Shalini, and Singh, V. K. Effect of preand post-emergence herbicides on weed 
dynamics, seed yield, and nutrient uptake in dwarf fieldpea. Journal of Food Legumes 27(2): 117-120 (2014).

13. Sharma, M. K., Sisodia, B. V. S. and Kanhaiya, L. Growth and trends of pulse production in India. Journal of Food Legumes 26 (1 and 2): 86-92 (2013).

14. Singh, G. and Sekhon, H. S. Integrated weed management in pigeonpea [Cajanus cajan (L). Millsp.] World Journal of Agricultural Sciences 9(1): 86-91 (2013).

15. Suman, S., Panwar, G. S., Mula, G. M. and Kumar, S. Performance of herbicide on yield and economic returns of pigeonpea [Cajanus cajan (L.) Millsp.] in Bihar. Green Farming 7(1): 123126(2016).
16. Talnikar, A. S., Kadam, D. R., Karande, D. R. and Jogdand, P. B. Integrated weed management in pigeonpea [Cajanus cajan (L). Miilsp.] International Journal of Agricultural Sciences 4: 363-370 (2008).

17. Varshney, J. G. Weed management in pigeonpea (Cajanus cajan L.) and greengram (Phaseolus radiatus) intercropping system. Indian Journal of Agricultural Science 63(1): 4-7 (1993).

18. Yadav, M. K. and Singh, R. S. Effect of nitrogen levels and weed management practices on pigeonpea (Cajanus cajan) and rice (Oryza sativa) intercropping system under ridge-furrow planting system. Indian Journal of Agricultural Science 79(4): 268-272 (2009). 